\title{
Transferts de technologie :les implications pour la politique suisse au développement
}

Formen des Technologietransfers : Folgerungen für die Schweizer

Entwicklungspolitik

\section{Rolf Weder}

\section{OpenEdition}

\section{Journals}

Édition électronique

URL : http://journals.openedition.org/aspd/1399

DOI : 10.4000/aspd.1399

ISSN : 1663-9669

Éditeur

Institut de hautes études internationales et du développement

Édition imprimée

Date de publication : 1 janvier 1991

Pagination : 235-253

ISSN : 1660-5934

Référence électronique

Rolf Weder, «Transferts de technologie :les implications pour la politique suisse au développement », Annuaire suisse de politique de développement [En ligne], 10 | 1991, mis en ligne le 14 avril 2013, consulté le 08 septembre 2020. URL : http://journals.openedition.org/aspd/1399 ; DOI : https:// doi.org/10.4000/aspd.1399

Ce document a été généré automatiquement le 8 septembre 2020

(c) The Graduate Institute / Geneva 


\section{Transferts de technologie :les implications pour la politique suisse au développement}

Formen des Technologietransfers : Folgerungen für die Schweizer

Entwicklungspolitik

\section{Rolf Weder}

\section{NOTE DE L'ÉDITEUR}

Lire l'article original en allemand dans Schweizerisches Jahrbuch für Entwicklungspolitik :

«Formen des Technologietransfers : Folgerungen für die Schweizer

Entwicklungspolitik », http://sjep.revues.org/1220. 